\title{
Evaluation of Sandbar Shiner as a Surrogate for Assessing Health Risks to the Endangered Cape Fear Shiner
}

\author{
Beth Chittick* and Michael Stoskopf \\ Environmental Medicine Consortium and Department of Clinical Sciences, \\ North Carolina State University, College of Veterinary Medicine, \\ 4700 Hillsborough Street, Raleigh, North Carolina 27606, USA \\ NORM HEIL \\ U.S. Fish and Wildlife Service, Warm Springs Fish Health Center, \\ Warm Springs, Georgia 31830, USA \\ JAY LEVINE \\ Environmental Medicine Consortium and Department of Farm Animal Health and \\ Resource Management, North Carolina State University, College of Veterinary Medicine, \\ 4700 Hillsborough Street, Raleigh, North Carolina 27606, USA \\ MAC LAW \\ Environmental Medicine Consortium and Department of Microbiology, Pathology, and \\ Parasitology, North Carolina State University, College of Veterinary Medicine, \\ 4700 Hillsborough Street, Raleigh, North Carolina 27606, USA
}

\begin{abstract}
The health status of the endangered Cape Fear shiner Notropis mekistocholas and the suitability of using the sympatric sandbar shiner $N$. scepticus as an investigative surrogate were evaluated. Forty Cape Fear shiners from three sites and 50 sandbar shiners from five sites were examined. Findings on gill biopsies, fin biopsies, and skin scrapings were limited to low levels of parasitism and gill aneurysms. Eighty-three bacterial isolates representing 13 aerobic species were cultured from the gastrointestinal tracts. A picornavirus was isolated from one pooled sample of sandbar shiners at one site. Forty-three percent of shiners (12 Cape Fear shiners, 27 sandbar shiners) had granulomas in various tissues of the body, 26\% (6 Cape Fear, 17 sandbar) had encysted trematodes, $16 \%$ (2 Cape Fear, 12 sandbar) had protozoal aggregates in muscle or connective tissue, and 26\% (22 Cape Fear shiners, 1 sandbar shiner) had mild, moderate, or moderately severe hepatic vacuolization. Other microscopic lesions included mild parasitism and degrees of inflammation in various tissues. Sandbar shiners appeared to be suitable surrogates for the Cape Fear shiner in bacteriological sampling; however, parasitic, viral, and nonhepatic histological lesions were more common in sandbar shiners. Findings from this study warrant further investigation of sandbar shiners as a conservative bioindicator species for the presence of potential health risks to Cape Fear shiners.
\end{abstract}

Population decline and threat of extinction for many freshwater fishes increased dramatically in the United States during the past 20 years (Warren and Burr 1994; Maitland 1995; Warren et al. 2000). Minnows are one of several freshwater fish groups at highest risk (Warren and Burr 1994; Whittier et al. 1997). In North Carolina, 21 of the 182 native freshwater fishes are now considered endangered, threatened, or vulnerable, including the endangered Cape Fear shiner Notropis mekistocholas (Warren and Burr 1994; Warren et al. 2000).

First described in 1971 (Snelson 1971), the Cape

* Corresponding author: beth_chittick@ncsu.edu

Received June 26, 2000; accepted December 28, 2000.
Fear shiner is now found in only five small populations within central North Carolina (Pottern and Huish 1987). Dam and reservoir construction, other changes in watershed use, river flooding, and habitat loss are thought to have contributed to the decline of this shiner (Pottern and Huish 1985). Increased human activity and development have altered the rocky, slow-moving riverine habitat thought necessary for survival and reproductive success of the Cape Fear shiner (Pottern and Huish 1985; U.S. Fish and Wildlife Service 1988). Other shiner species, such as the sandbar shiner $N$. scepticus, appear to have adapted and continue to thrive in ecosystems where Cape Fear shiner populations have not (Pottern and Huish 1985, 1986, 1987).

Surrogate cyprinid species have been used pre- 
viously in toxicological and physiological research (Beyers 1995; Ruppert and Muth 1997; Jones et al. 1998; Rakes et al. 1999) and in health assessment studies involving endangered species (Robinson et al. 1998). Surrogates are defined as substitutes and are often selected on the basis of taxonomic, ecological, anatomical, and behavioral similarities (Mish 1986; Purvis et al. 1998; Robinson et al. 1998). The sympatric congenerous sandbar shiner could potentially serve as a surrogate for health diagnostic sampling without impacting the endangered Cape Fear shiner populations. Both species of shiners grow to roughly the same size, inhabit similar habitats of small streams and flowing pools near rocky riffles in the North Carolina Cape Fear Drainage, and often swim together in large mixed schools (Harrell and Cloutman 1978; Pottern and Huish 1985; U.S. Fish and Wildlife Service 1988). Little is known about the breeding behavior of the Cape Fear shiner, though sandbar shiners reach sexual maturity at age 2 years and spawn from late May through early July (Harrell and Cloutman 1978; Pottern and Huish 1985). The two species differ in the length of their gastrointestinal tracts, the longer intestine of the Cape Fear shiner being more indicative of a herbivorous nature than the shorter intestine of the sandbar shiner, which is considered a carnivorous sight feeder (Snelson 1971; Harrell and Cloutman 1978). Major diet components of the sandbar shiner in South Carolina are terrestrial and aquatic insects, with plant material and algae apparently being important only in winter months (Harrell and Cloutman 1978). Such similarities and differences must be considered when conducting a health assessment of a possible surrogate. A valid surrogate, however, would allow potential health risks to Cape Fear shiners to be more readily assessed for future augmentation and reintroduction programs. In this study, we evaluated the health status of the endangered Cape Fear shiner and the suitability of the sandbar shiner as a surrogate.

\section{Methods}

Site selection.-Five North Carolina sites representing current and historical habitat of the Cape Fear shiner were sampled. Each site also represented a potential future augmentation or reintroduction site for Cape Fear shiners. Site 1 was the confluence of the Rocky and Deep Rivers in Chatham and Lee counties; site 2, the Rocky River in Chatham County upstream of the hydroelectric reservoir; site 3, the Haw River in Chatham County; site 4 , the Deep River in Moore County down- stream of High Falls; and site 5, the Deep River in Randolph and Moore counties upstream of High Falls.

Sampling protocol.-Shiners were collected over a 2 -d period with a $0.18 \times 0.37$-m nylon mesh seine with $0.38-\mathrm{cm}$-diameter holes and leads every $15.2 \mathrm{~cm}$. Fish were transferred by hand from the seine to plastic bags for transport. Original plans called for collecting 10 Cape Fear shiners and 10 sandbar shiners at each of the five sites. However, low population numbers of the Cape Fear shiners at sites 2 and 3 precluded lethal diagnostic sampling at these sites. Sufficiently robust populations at sites 1 and 4 allowed collection of an additional five Cape Fear shiners at these sites for comparison with the sandbar shiners. Ultimately, 15 Cape Fear shiners were collected from sites 1 and 4 and 10 from site 5, whereas 10 sandbar shiners were collected from each of the five sites.

Shiners were transported and held in plastic bags at ambient temperature for no longer than $2 \mathrm{~h}$ before lethal diagnostic sampling. Fish were killed with a $500 \mathrm{mg} / \mathrm{L}$ solution of tricaine methanesulfonate (MS-222; Argent Chemical Laboratories, Redmond, Washington). Total lengths were measured (Hubbs and Lagler 1958) and weights were determined with an electronic gram scale.

The fish were evaluated for external lesions, and skin scrapings, gill biopsies, and pectoral fin biopsies were collected. Wet mounts of these scrapings and biopsies were evaluated immediately by light microscopy. The left side of the body wall was doused with 70\% isopropyl alcohol for an aseptic approach to the coelomic cavity for microbiological sampling. The spleen and portions of the liver, caudal kidney, and intestinal tract were removed aseptically and placed collectively in Hank's balanced salt solution (HBSS) for viral isolation. Because of the small size of the fish, samples for virological analysis were pooled by species, in groups of five fish, to improve the likelihood of viral isolation. The remaining intestine was then incised with a scalpel and ingesta was collected with a $1-\mu \mathrm{L}$ disposable inoculating loop and streaked on brain heart infusion agar (BHIA) for bacteriological culture. The caudal peduncles of the Cape Fear shiners were severed, placed on dry ice, and later frozen at $-70^{\circ} \mathrm{C}$ for future genetic analysis. The left otolith was removed from each fish for future determination of the age of the fish (Kimura et al. 1979; Pawson 1990). The remainder of each fish was individually stored in $10 \%$ neutral buffered formalin for routine histological processing (Bullock 1989). 
Histology.-After paraffin embedding of formalin-fixed tissues, 6- $\mu \mathrm{m}$-thick midsagittal and parasagittal sections of the entire head and body of each fish were stained with hematoxylin and eosin and evaluated by light microscopy (Bullock 1989). Special stains, including Fite's acid fast, periodic acid Schiff, Giemsa, and Gomori's methenamine-silver stains, were used when appropriate to evaluate lesions. Organs evaluated histologically included integument, eye, brain, gills, pseudobranch, liver, gallbladder, anterior kidney, caudal kidney, gonad, pancreas, gastrointestinal tract, heart, skeletal muscle, bone, spinal cord, swim bladder, and accessory splenic tissue. The overall appearance of hepatocellular vacuolization was subjectively graded according to the following classification scheme: 1 , none or very mild (vacuolization made up $<25 \%$ of individual hepatocytes and affected $<50 \%$ of the hepatic parenchyma in all fields); 2, mild (vacuolization made up $<25 \%$ of the hepatocyte and affected $>50 \%$ of the hepatic parenchyma in all fields); 3 , moderate (vacuolization made up $25 \%$ or more of the hepatocyte and affected $>50 \%$ of the hepatic parenchyma in all fields); 4, moderately severe (vacuolization made up $25 \%$ or more of the hepatocyte and affected $>75 \%$ of the hepatic parenchyma in all fields); 5, severe (vacuolization made up $>25 \%$ of the hepatocyte and diffusely affected $>90 \%$ of the hepatic parenchyma in all fields).

Bacteriology and virology.-Samples for bacteriological (Elliott 1994) and virological (Ganzhorn and LaPatra 1994) analyses were processed at the U.S. Fish and Wildlife Service (USFWS) Warm Springs Fish Health Center, Warm Springs, Georgia, in accordance with procedures outlined by the American Fisheries Society with minor modifications as indicated in the 1995 USFWS Fisheries-Fish Health Policy guidelines (U.S. Fish and Wildlife Service 1995). Bacterial samples from the primary isolation slants were further cultured on BHIA plates by the streak dilution method to obtain pure culture isolates. Pure culture isolates were then transferred to BHIA slants for additional growth and identification. Identification of culture isolates as to genus or species was performed by using standard biochemical tests and identification schemes, including the Minitek Miniaturized Microorganism Differentiation System (Becton Dickinson Microbiology Systems, Cockeysville, Maryland). All bacterial cultures were maintained and tested at $22^{\circ} \mathrm{C}$.

Viral assays were performed with cell lines of fathead minnow Pimephales promelas (FHM) and
Epithelioma papillosum cyprini (EPC; Bullock 1989). Pooled virological samples were processed by decanting the HBSS storage solution, weighing the sample, and diluting each sample 1:10 (weight: volume) in HBSS. Samples were homogenized with a stomacher (Seward Medical Ltd., London, UK) for $45 \mathrm{~s}$. Samples were then diluted 1:100 in HBSS, centrifuged at 3,000 revolutions per minute for $20 \mathrm{~min}$ at $4^{\circ} \mathrm{C}$, and held overnight at $4^{\circ} \mathrm{C}$. Eight $0.1-\mathrm{mL}$ replicates from each sample pool were placed in 96-well plates. Plate wells were overlaid with a minimum essential media containing $10 \%$ fetal bovine serum (MEM-10) cell suspension, sealed with plate sealers, and incubated at $20^{\circ} \mathrm{C}$ for $14 \mathrm{~d}$. During this 2-week incubation, plates were observed daily for cytopathic effect (CPE) (Bullock 1989). If CPE or toxicity was observed, cell culture supernatant from suspect wells was aspirated and filtered with a $0.45-\mu \mathrm{m}$ (pore size) syringe filter. Filtered fluid was then serially diluted $10^{-1}$ to $10^{-5}$ and replated in cell culture as described above. Cultures were observed daily for $\mathrm{CPE}$. If CPE was noted, the suspect virus was characterized by routine transmission electron microscopy, DNA synthesis inhibitor assays, and exposure to chloroform (Iwanowicz et al. 2000).

Statistical analyses.-Sample size calculations were performed to assess the number of fish needed to detect health risks greater than $25 \%$ in the population with 95\% confidence (Ossiander and Wedemeyer 1973; Dubin and Zietz 1991). Although sample size was restricted by conservation concerns it was still sufficient for determination of high-prevalence health risks that could impact endangered fish populations. Data were initially stratified by length, gender, and site for analysis. Potential independent associations between lengths, weights, and gender with shiner species were evaluated by two-tail Fisher's exact tests (Glantz 1997), with a probability value of less than 0.05 considered significant. Significant differences in lengths and weights of Cape Fear shiners from site 1 and genders of sandbar shiners at site 4 precluded complete statistical analysis of potential species and site specific differences in lesion distributions.

\section{Results}

Ninety shiners were evaluated, 40 Cape Fear shiners and 50 sandbar shiners, from three and five sites, respectively. Gender distribution at the five sampling sites was similar except at site 4 , where 10 females but no male sandbar shiners were collected (Table 1). Gender differences in sandbar 
TABLE 1.-Distribution of gender, total lengths, and weights of Cape Fear shiners and sandbar shiners at each collection site.

\begin{tabular}{|c|c|c|c|c|c|c|c|c|c|c|c|c|}
\hline \multirow[b]{2}{*}{ Species } & \multirow[b]{2}{*}{ Site } & \multirow[b]{2}{*}{ q } & \multirow[b]{2}{*}{$\hat{0}$} & \multirow[b]{2}{*}{$N$} & \multicolumn{4}{|c|}{ Weights (g) } & \multicolumn{4}{|c|}{ Total lengths $(\mathrm{cm})$} \\
\hline & & & & & Median & $\begin{array}{c}25 \%, 75 \% \\
\text { quartiles }\end{array}$ & Mean & SD & Median & $\begin{array}{c}25 \%, 75 \% \\
\text { quartiles }\end{array}$ & Mean & SD \\
\hline \multirow{4}{*}{$\begin{array}{l}\text { Cape Fear } \\
\text { shiner }\end{array}$} & All & 23 & 17 & 40 & 2.90 & $1.73,3.24$ & 2.63 & 0.85 & 6.9 & $5.9,7.3$ & 6.7 & 0.7 \\
\hline & 1 & 8 & 7 & 15 & 1.51 & $1.35,1.94$ & 1.72 & 0.48 & 5.9 & $5.7,6.3$ & 6.1 & 0.5 \\
\hline & 4 & 9 & 6 & 15 & 3.16 & $2.93,3.57$ & 3.21 & 0.41 & 7.2 & $7.0,7.4$ & 7.2 & 0.3 \\
\hline & 5 & 6 & 4 & 10 & 3.24 & $2.85,3.51$ & 3.15 & 0.52 & 7.1 & $6.3,7.4$ & 6.9 & 0.6 \\
\hline \multirow{6}{*}{$\begin{array}{r}\text { Sandbar } \\
\text { shiner }\end{array}$} & All & 30 & 20 & 50 & 3.08 & $2.44,4.13$ & 3.32 & 1.16 & 7.4 & $6.8,7.9$ & 7.4 & 0.8 \\
\hline & 1 & 6 & 4 & 10 & 3.89 & $3.48,4.56$ & 3.98 & 0.72 & 7.8 & $7.7,8.2$ & 7.9 & 0.4 \\
\hline & 2 & 5 & 5 & 10 & 2.74 & $2.17,3.01$ & 2.65 & 0.53 & 7.3 & $6.8,7.5$ & 7.1 & 0.4 \\
\hline & 3 & 5 & 5 & 10 & 4.42 & $3.26,5.45$ & 4.28 & 1.20 & 8.2 & $7.0,8.6$ & 7.9 & 0.8 \\
\hline & 4 & 10 & 0 & 10 & 2.31 & $1.63,2.88$ & 2.57 & 1.32 & 6.8 & $6.0,7.0$ & 6.7 & 0.9 \\
\hline & 5 & 4 & 6 & 10 & 3.13 & $2.67,3.66$ & 3.15 & 0.82 & 7.4 & $6.9,7.6$ & 7.3 & 0.6 \\
\hline
\end{tabular}

shiners were statistically significant between site 4 and sites $2(P=0.03), 3(P=0.03)$, and $5(P$ $=0.01)$ but not site $1(P=0.09)$. No statistically significant gender differences were noted in Cape Fear shiners between sites $(P=1.0)$.

Lengths of sandbar shiners collected at the five sites ranged from 6.0 to $9.0 \mathrm{~cm}$, and weights ranged from 1.55 to $6.04 \mathrm{~g}$ (Table 1). Lengths and weights for the sandbar shiners were fairly consistent at all five sites. Lengths of Cape Fear shiners collected at the three sites ranged from 5.5 to $7.8 \mathrm{~cm}$, and weights ranged from 1.28 to $4.14 \mathrm{~g}$ (Table 1). Median lengths and weights of the Cape Fear shiners collected at site 1, however, were significantly less than those sampled at sites $4(P<$ $0.01)$ and $5(P<0.03)$.

No clinically observable external abnormalities were noted on any of the fish in the study. Internally, the only gross lesions identified were from Cape Fear shiners: diffusely pale yellow livers in one fish from site 5 and in four from site 1 . Additionally, one Cape Fear shiner from site 5 had a pale yellow caudal kidney at necropsy.

Findings on gill biopsies, fin biopsies, and skin scrapes included occasional aneurysms with mild focal erythema and ballooning of gill lamellae in eight Cape Fear shiners, six from site 1 and two from site 5. Trichodina species were identified in two sandbar shiners from site 3 . One of the latter also showed a Chilodonella-like species on skin scrape. The only other wet mount findings were gill cysts $21-32 \mu \mathrm{m}$ in diameter in seven shiners, two sandbar shiners and five Cape Fear shiners, from four of the five sites sampled. No fish from site 3 was found to have any gill cysts on gill biopsy. Moreover, none of the seven fish with cysts noted on gill biopsy had similar lesions noted on gill histopathology. Conversely, two Cape Fear shiners and three sandbar shiners with histological evidence of gill cysts had no observed gill cysts on wet mounts.

From the 90 fish sampled, 83 isolates representing 13 aerobic bacterial species were cultured from the gastrointestinal tracts (Table 2). Distribution of gastrointestinal bacterial species was similar in Cape Fear shiners and sandbar shiners at sites 1, 4, and 5, where both fishes were collected. Twenty of the shiners had two or more isolates cultured, whereas 39 individuals grew only one bacterial species from the intestine. Overall, the predominant bacteria grown in both species of shiners were Acinetobacter spp. (in $44 \%$ of fish sampled) and Pseudomonas spp. (in 23\%). Thirty-one shiners (34\% of fish sampled), 14 Cape Fear shiners and 17 sandbar shiners, showed no bacterial growth from gastrointestinal contents. Only one viral isolate, a picornavirus, was obtained from the pooled samples of spleen, liver, kidney, and intestine collected from five sandbar shiners at site 5 .

Of the 90 shiners sampled, 39 (43\%) had granulomas in various tissues of the body, $23(26 \%)$ had encysted trematodes, $14(16 \%)$ had protozoal aggregates in muscle or connective tissue, and 23 (26\%) had mild, moderate, or moderately severe hepatic vacuolization (Table 3). Other microscopic lesions included mild parasitism and different degrees of inflammation in various tissues (Table 3 ).

Granulomas were oval to irregularly shaped encapsulated structures comprising small numbers of epithelioid macrophages surrounding small amounts of eosinophilic, amorphous material and necrotic debris. Granulomas were found in $20 \%$ to $80 \%$ of each shiner species at each collection site-12 Cape Fear shiners and 27 sandbar shiners overall-and were found in multiple organs of the affected fish: $52 \%$ of shiners had granulomas in the pancreas, $41 \%$ in the gastrointestinal walls, $36 \%$ in coelomic mesentery, and $13 \%$ in the liver. Occasionally, granulomas 
TABLE 2.-Number of aerobic bacterial isolates cultured from the intestines of Cape Fear shiners (Nm) and sandbar shiners (Ns) at each collection site.

\begin{tabular}{|c|c|c|c|c|c|c|c|c|c|c|c|c|c|}
\hline \multirow[b]{2}{*}{ Bacterial species } & \multirow[b]{2}{*}{ Total } & \multirow[b]{2}{*}{$\mathrm{Nm}$} & \multirow[b]{2}{*}{ Ns } & \multicolumn{2}{|c|}{ Site 1} & \multicolumn{2}{|c|}{ Site $2^{\mathrm{a}}$} & \multicolumn{2}{|c|}{ Site $3^{\mathrm{a}}$} & \multicolumn{2}{|c|}{ Site 4} & \multicolumn{2}{|c|}{ Site 5} \\
\hline & & & & $\mathrm{Nm}$ & Ns & $\mathrm{Nm}$ & Ns & $\mathrm{Nm}$ & Ns & $\mathrm{Nm}$ & Ns & $\mathrm{Nm}$ & Ns \\
\hline Acinetobacter spp. & 40 & 17 & 23 & 2 & 2 & & 5 & & 6 & 10 & 7 & 5 & 3 \\
\hline Pseudomonas spp. & 21 & 11 & 10 & 3 & 4 & & 1 & & 1 & 5 & 3 & 3 & 1 \\
\hline Enterobacter spp. & 6 & 3 & 3 & 1 & 0 & & 1 & & 2 & 2 & 0 & 0 & 0 \\
\hline Pasteurella spp. & 4 & 2 & 2 & 0 & 0 & & 0 & & 1 & 1 & 1 & 1 & 0 \\
\hline Staphylococcus spp. & 3 & 0 & 3 & 0 & 1 & & 1 & & 1 & 0 & 0 & 0 & 0 \\
\hline Citrobacter spp. & 2 & 0 & 2 & 0 & 0 & & 0 & & 0 & 0 & 1 & 0 & 1 \\
\hline Aeromonas hydrophila & 1 & 1 & 0 & 1 & 0 & & 0 & & 0 & 0 & 0 & 0 & 0 \\
\hline Aeromonas sobria & 1 & 0 & 1 & 0 & 0 & & 1 & & 0 & 0 & 0 & 0 & 0 \\
\hline Shigella spp. & 1 & 1 & 0 & 1 & 0 & & 0 & & 0 & 0 & 0 & 0 & 0 \\
\hline Bacillus spp. & 1 & 1 & 0 & 0 & 0 & & 0 & & 0 & 1 & 0 & 0 & 0 \\
\hline Lactobacillus spp. & 1 & 0 & 1 & 0 & 1 & & 0 & & 0 & 0 & 0 & 0 & 0 \\
\hline Serratia spp. & 1 & 1 & 0 & 0 & 0 & & 0 & & 0 & 1 & 0 & 0 & 0 \\
\hline Streptococcus spp. & 1 & 0 & 1 & 0 & 0 & & 0 & & 1 & 0 & 0 & 0 & 0 \\
\hline No growth & 31 & 14 & 17 & 8 & 5 & & 3 & & 2 & 2 & 1 & 4 & 6 \\
\hline Total & 114 & 51 & 63 & 16 & 13 & & 12 & & 14 & 22 & 13 & 13 & 11 \\
\hline
\end{tabular}

a No Cape Fear shiners collected.

TABLE 3.- Histological findings in Cape Fear shiners and sandbar shiners at all five collection sites.

\begin{tabular}{|c|c|c|c|c|}
\hline \multirow[b]{2}{*}{ Organ } & \multirow[b]{2}{*}{ Histological finding } & \multicolumn{3}{|c|}{ Number of lesions $(\%)^{\mathrm{a}}$} \\
\hline & & All & $\begin{array}{l}\text { Cape Fear } \\
\text { shiners }\end{array}$ & $\begin{array}{c}\text { Sandbar } \\
\text { shiners }\end{array}$ \\
\hline \multirow[t]{5}{*}{ Liver } & Hepatocellular vacuolization & $23(25.6)$ & $22(55.0)$ & $1(2.0)$ \\
\hline & Mild multifocal random macrophage aggregates & $5(5.5)$ & 0 & $5(10.0)$ \\
\hline & Granulomas & $5(5.5)$ & $1(2.5)$ & $4(8.0)$ \\
\hline & Mild focal mononuclear cell infiltrate & $4(4.4)$ & $2(5.0)$ & $2(4.0)$ \\
\hline & Mild random eosinophilic foci & $1(1.1)$ & $1(2.5)$ & 0 \\
\hline \multirow[t]{4}{*}{ Coelom/mesentery } & Granulomas & $15(16.7)$ & $6(15.0)$ & $9(18.0)$ \\
\hline & Encysted trematodes & $9(10.0)$ & $4(10.0)$ & $5(10.0)$ \\
\hline & Protozoa (myxozoans) & $1(1.1)$ & 0 & $1(2.0)$ \\
\hline & $\begin{array}{l}\text { Mild focal mononuclear cell infiltrate in } \\
\text { cranial coelom }\end{array}$ & $1(1.1)$ & 0 & $1(2.0)$ \\
\hline \multirow{3}{*}{ Pancreas } & Granulomas & $20(22.2)$ & $5(12.5)$ & $15(30.0)$ \\
\hline & Protozoa (myxozoans) & $1(1.1)$ & 0 & $1(2.0)$ \\
\hline & Moderate multifocal granulomatous pancreatitis & $1(1.1)$ & 0 & $1(2.0)$ \\
\hline \multirow[t]{4}{*}{ Muscle } & Protozoa (myxozoans) & $11(12.2)$ & $1(2.5)$ & $10(20.0)$ \\
\hline & Encysted trematodes & $8(8.9)$ & 0 & $8(16.0)$ \\
\hline & Granulomas & $2(2.2)$ & $2(5.0)$ & 0 \\
\hline & Mild focal chronic myositis & $1(1.1)$ & 0 & $1(2.0)$ \\
\hline \multirow[t]{5}{*}{ Gastrointestinal tract } & Granulomas & $16(17.8)$ & $1(2.5)$ & $15(30.0)$ \\
\hline & Mild diffuse chronic enteritis & $1(1.1)$ & $1(2.5)$ & 0 \\
\hline & Protozoa (myxozoans) & $1(1.1)$ & 0 & $1(2.0)$ \\
\hline & Moderate diffuse chronic enteritis & $1(1.1)$ & 0 & $1(2.0)$ \\
\hline & Trematode in intestinal lumen & $1(1.1)$ & 0 & $1(2.0)$ \\
\hline \multirow[t]{6}{*}{ Gills } & Circular deeply basophilic cysts & $5(5.5)$ & $2(5.0)$ & $3(6.0)$ \\
\hline & Granulomas & $1(1.1)$ & $1(2.5)$ & 0 \\
\hline & Mild multifocal lymphocytic branchitis & $1(1.1)$ & 0 & $1(2.0)$ \\
\hline & Moderate focal chronic branchitis (associated & & & \\
\hline & with gill cyst) & $1(1.1)$ & 0 & $1(2.0)$ \\
\hline & Mild aneurysms & $1(1.1)$ & $1(2.5)$ & 0 \\
\hline \multirow[t]{2}{*}{ Cranial connective tissue } & Encysted trematodes & $6(6.7)$ & $2(5.0)$ & $4(8.0)$ \\
\hline & Protozoa (myxozoans) & $1(1.1)$ & $1(2.5)$ & 0 \\
\hline Pseudobranch & Granulomas & $1(1.1)$ & 0 & $1(2.0)$ \\
\hline Skin & Mild focal lymphocytic dermatitis & $1(1.1)$ & $1(2.5)$ & 0 \\
\hline Caudal kidney & Mild focal lymphocytic interstitial nephritis & $1(1.1)$ & 0 & $1(2.0)$ \\
\hline Head kidney & Dilation of vascular channels & $1(1.1)$ & 0 & $1(2.0)$ \\
\hline Spleen & Marked congestion & $1(1.1)$ & 0 & $1(2.0)$ \\
\hline Heart & Mild focal chronic myocarditis & $1(1.1)$ & 0 & $1(2.0)$ \\
\hline
\end{tabular}

a For both species combined, parentheses indicate percentage of all shiners sampled with the histological lesion. For individual species, parentheses indicate percentage of specified shiner species sampled with the histological lesion. 
were also noted in skeletal muscle, kidney, gills, or pseudobranch. One sandbar shiner from site 4 had abundant acid-fast positive rods associated with more numerous granulomas in multiple organs, including kidney, liver, intestine, and ovary. However, no mycobacteria were isolated from the gastrointestinal bacterial samples from this individual.

Encysted trematodes were identified in $23(26 \%)$ of all shiners sampled, 6 Cape Fear shiners and 17 sandbar shiners. These parasites were noted in 5 of the 10 Cape Fear shiners sampled at site 5. No encysted trematodes were seen in fish from site 3 but were present in two to six sandbar shiners at each of the other four sites.

Twelve sandbar shiners and two Cape Fear shiners were found to have myxozoan aggregates in various tissues. Elliptical aggregates of bipolar, operculated, slightly refractile spores with two polar capsules were identified in the skeletal muscle or connective tissue of these 14 shiners (16\% of the fish examined) over four sites. A similar aggregate was noted in the gastrointestinal tract of one fish and in the pancreas of another. None of these parasites was noted in any fish from site 3 . The Giemsa-positive staining of the polar capsules of these parasites was consistent with a diagnosis of myxozoanosis (Gardiner et al. 1988).

Hepatocellular vacuolization was noted in 23 shiners (26\%), 22 Cape Fear shiners and one sandbar shiner. This histological liver change was noted in only two Cape Fear shiners from site 1, but 12 and 8 Cape Fear shiners from sites 4 and 5, respectively, were affected. The only sandbar shiner showing hepatocellular vacuolization came from site 5. Affected Cape Fear shiners displayed predominately mild (grade 2: 61\%) or moderate (grade 3: 35\%) hepatocellular vacuolization, although one from site 4 showed moderately severe (grade 4) lesions. In the only sandbar shiner with this lesion, hepatocellular vacuolization was mild.

\section{Discussion}

Habitat health risk assessment is a relatively new tool used to improve prognostication and site selection decisions for planning augmentation, translocation, or introduction of species. The process is challenging in the best circumstances but becomes even more difficult when dealing with an endangered species that has not been studied extensively. The total lack of knowledge about what diseases might affect the survival potential of Cape Fear shiners and the relative paucity of reported diseases in the general taxon of shiners required us to apply diagnostic techniques used in distantly related species. In favor of this approach, however, any information discovered about disease or pathogen prevalences in these Cape Fear shiners would greatly enhance our understanding of their health challenges.

To reliably identify environmental factors that might influence the overall health of the species, we ideally would gather data from a large number of sites where the species is found. Unfortunately, the Cape Fear shiner survives in only five known populations, all located relatively near to one another. Of these five populations, only three were considered adequately stable by the biologists studying the species to allow lethal sampling. With so few sites, extreme caution must be exercised in trying to relate any differences in health risk parameters observed between the sites to the sites themselves, unless those differences are extremely dramatic. One intersite difference identified in our study was the smaller size of the Cape Fear shiners from site 1 compared with those collected from sites 4 and 5 . The Cape Fear shiners from site 1 were actually closer in size to historically recorded sizes than were those from the other two sites. In the early 1970s, Snelson recorded adult lengths of 4.5-6.0 cm for Cape Fear shiners collected from the Cape Fear drainage (Snelson 1971); more recently, adult lengths have been listed between 5 and $6 \mathrm{~cm}$ (Menhinick 1991). Although the lower lengths and weights at site 1 might be attributable to a younger population sampled, to local strain variation, or to stunting through malnutrition, the shiners from site 1 appeared to be in good condition on gross examination. Alternatively, perhaps the animals from sites 4 and 5 had grown particularly large because of high food availability. Site 1 animals may be more representative of normal morphometrics.

The collection of only female sandbar shiners at site 4 was most likely an extreme example of chance but deserves further investigation in future collections from that site. Although alteration of the sex ratio through exposure to estrogenic compounds cannot be ruled out (Kime 1998), the collection of 6 males (of the 15 Cape Fear shiners collected from the same site) reduces the likelihood of that scenario. Site 4 was also unique because none of the Cape Fear shiners collected there had detectable aneurysms, focal erythema, or lamellar ballooning in gill biopsies-conditions present in fish from all the other sites studied. The impact of this finding is somewhat muted by our inability to document similar lesions in the fixed tissues collected from the same animals. This im- 
plies either that biopsy is a more sensitive tool than histology for documenting these gill conditions or that collection and handling of the gill biopsies may have produced artifacts that do not portend disease.

The other apparent site-related difference of note was the finding of protozoal gill infestations with Trichodina spp. and Chilodonella-like organisms in sandbar shiners from site 3 . This combined with site 3 being the only site where parasitic cysts in the gill were not detected in biopsies or histology suggests a possible difference in the protozoal community of site 3 compared with the other sites sampled. Trichodina species have been described in other Notropis species, including infestations of the gills of emerald shiners $N$. atheroides (Muzzall and Peebles 1987) and in urinary bladders and ureters of common shiners Luxilus (formerly $\mathrm{No}$ tropis) cornutus ( $\mathrm{Li}$ and Desser 1983). The apparent increased prevalence of gill ciliates at site 3 deserves careful consideration.

When the number of sites that can be examined is limited, valuable information can still be obtained by gathering cross-sectional samples from the populations at available sites. The confidence in the reliability of the prevalence determined for a pathogen or condition at a sampled site depends on the number of specimens that can be sampled. The minimum sample size for strong confidence $(95 \%)$ of detecting conditions with relatively low prevalences $(5 \%)$ is generally agreed to be $30-40$ individuals from a site (Ossiander and Wedemeyer 1973; Dubin and Zietz 1991). Unfortunately, not only is the Cape Fear shiner limited to a few sites, but also it is limited in number at these sites. The sampling problem is further exacerbated because nonlethal sampling methods have not been developed or well-validated in fish this small. Because the diagnostic processes used required permanent removal of individuals from the small extant populations, the sample sizes for each site in our study were necessarily based on the demographic assessments made by the species' biologists. This led us to modify our original design, which would have sampled equal numbers of both fish species from each site. The maximum sample numbers per site - 10 or 15 individuals - meant that we could have $95 \%$ confidence in detecting diseases or conditions only for those having true prevalences in excess of $25 \%$ at a given site (Ossiander and Wedemeyer 1973; Dubin and Zietz 1991). Because many diseases cycle within populations, a low prevalence at a given time does not mean that a disease does not have the potential for devastating a population under the right conditions. Nevertheless, identification of the diseases or conditions at higher prevalences in populations can provide valuable insight into potential population threats and help identify conditions for further study.

In our study, we were able to identify several conditions that merit further consideration. The pathogenesis of the mild telangectasis and focal erythema of the gills observed in several Cape Fear shiners from multiple sites deserves further investigation, as do the etiology and impact of the unidentified parasitic gill cysts present in both fish species at most sites. Similarly, the pathogenic potential of the trichodinid and Chilodonella-like organisms found infesting the gills of the fish collected from site 3 only, where the Cape Fear shiner population is smaller than at the other two sites sampled, strongly suggests the need to focus on ciliate gill parasites in assessing health risks in a Cape Fear shiner habitat.

The small numbers of encysted digenetic trematodes in both shiner species are consistent with that expected for wild fish populations (Wootten 1989). A previous study of emerald shiners identified digenean trematodes of five genera in the majority of fish sampled (Muzzall and Peebles 1974). Positive findings of digenetic trematodes in Cape Fear shiners at two of the three sites sampled and in sandbar shiners at four of the five sites sampled indicate that the small sample sizes did not affect our ability to detect these conditions.

Digenean trematode cysts were found in more than $25 \%$ of shiners sampled in this study, and chronic degradation of parasitic cysts most likely accounts for the histological findings of granulomas in the gastrointestinal walls, pancreas, and coelomic mesenteries of several shiners from different sampling sites. However, granulomas of one sandbar shiner from site 4 contained abundant acid-fast staining rods consistent with a disseminated mycobacterial infection. Although gastrointestinal cultures did not confirm the presence of Mycobacteria spp., possibly no mycobacteria were being shed into the intestinal lumen, or overgrowth of other intestinal flora during bacterial isolation obscured the finding. The detection of this infection, even at only one site in one fish, is quite important considering the low number of fish sampled at each site and the potential ramifications for future efforts to restore Cape Fear shiners at this particular site. Use of selective mycobacterial media, optimization of incubation protocols for detection of mycobacteria, and bacterial culture of tissues likely to be affected by mycobacterial gran- 
ulomas should be included in future health risk assessment protocols for the Cape Fear shiner.

The size of the fish and the complex multicomponent design of the study necessitated several choices in prioritizing tissues for laboratory testing. The pooling of samples for viral isolation to obtain sufficient tissue for successful isolation is an example of these compromises. The identification of a picorna-like virus from a pooled sample of sandbar shiners presented a previously undescribed viral species (Iwanowicz et al. 2000). Picorna-like viruses have been documented in salmonids, Australian sea bass, Japanese parrotfish, red-spotted grouper, striped jack, and rainbow smelt (McAllister 1993a, 1993b; Noga 1996). Picorna-like viruses have been implicated in neurological signs in juvenile fish, mortality events in smelt, and focal hepatitis and mild hematopoietic necrosis in salmonids, but some fish species show no clinical signs of disease with experimental infections (McAllister 1993a, 1993b; Noga 1996). Histological lesions in the group of sandbar shiners that provided the isolate were nonspecific, including mild parasitism with encysted trematodes, protozoans, and gill cysts. One individual had a mild branchitis, a second had mild hepatocellular vacuolization, and a third had gastrotintestinal granulomas on histological examination. None of the fish contributing to the pool showed signs of clinical disease at the time of sampling. The pathogenicity of this virus is unknown, but it must be considered in the decision-making process for future augmentation or reintroduction efforts. The identification of a potentially new virus in this very limited investigation emphasizes the importance of including viral isolation efforts in preliminary assessments of habitat health risks.

Validation of noninvasive sampling techniques would greatly enhance our ability to gather larger sample numbers with potentially less impact on endangered populations. Nonlethal diagnostic tests are particularly difficult with very small fish. In our studies all fish were killed shortly before biopsy, which prevented us from assessing the impact of our battery of clinical tests on the survivability of the fish tested. We found it physically feasible, however, to obtain suitable fin biopsies, impression smears, and gill biopsies with unsophisticated equipment in a way that in most cases would not be expected to compromise the fish. Comparing gill biopsy results with histological examination of gill tissue suggests that gill biopsy may be more effective in detecting motile ciliate protozoans such as Trichodina spp. Gill biopsy also detected telangectasis and gill erythema in eight fish, only one of which was confirmed by postmortem histological examination of the gills. Conversely, gill biopsy was not a sensitive technique for diagnosing the presence of presumed parasitic cysts in the gills found in the histological examinations in this study. Fin biopsies and mucus impression smears did not reveal the presence of any external pathogenic parasites, nor were any detected on histopathology. Accordingly, we are unable to reliably judge the sensitivity or accuracy of those nonlethal diagnostic tests. The further development and validation of nonlethal testing for use in small fishes should remain a priority of investigators.

Using surrogate animals to evaluate habitat health risk is controversial. A primary requirement that the surrogate exist in thriving populations in similar or identical habitats essentially guarantees the target and surrogate species will have important physiologic or behavioral differences. Therefore the selection of a surrogate is always a compromise. The elongate, coiled intestine of the Cape Fear shiner differentiates it from other shiners of the genus Notropis, which have a characteristic short intestine (Snelson 1971). Despite the large differences in digestive tract morphology between sandbar and Cape Fear shiners, the gastrointestinal flora of these species was similar. This suggests the potential usefulness of the sandbar shiner as a surrogate for evaluating the presence of bacterial diseases that might affect Cape Fear shiners.

Encysted trematodes identified in this study were not identified to species. The two shiner species may have different susceptibilities or capacities to serve as intermediate hosts for specific trematodes. Overall cyst loads, however, were roughly similar for Cape Fear shiners and sandbar shiners in this study. This suggests the surrogate species has the potential to provide adequate representation of trematode presence in the endangered shiner population.

In general, parasitic and nonhepatic histological lesions were noted more frequently in sandbar shiners than in Cape Fear shiners in this study. Aggregates of parasitic spores found in the skeletal muscle of individuals of both shiner species and from fish obtained from four of the five sites sampled suggest this is a prevalent condition. The staining characteristics, morphology, localization in the fish, and lack of inflammatory reaction around the parasitic cysts suggest these are myxozoan parasites. The myxosporidian Dicauda atherinoidi has been previously described in emerald 
shiners (Hoffman and Walker 1978). The much greater prevalence of these putative myxozoan parasites in the sandbar shiners we sampled suggests that the surrogate species may overrepresent the myxozoan burden in Cape Fear shiners. The sandbar shiner therefore potentially represents a conservative and comparatively sensitive bioindicator of the presence of potential pathogens that could pose a risk to Cape Fear shiner populations.

Conversely, hepatocellular vacuolization was more frequently observed in the endangered Cape Fear shiners than in the sandbar shiners in our study. This lesion is relatively nonspecific, having been previously associated with conditions ranging from chronic stress, dietary deficiencies and excesses, and various toxicities, including environmental contaminations (Roberts 1989; Myers et al. 1998; Adams et al. 1999). In our study, the differences in prevalence between the two species could represent species-specific responses to the environmental, dietary, or stress conditions. As such, the lower prevalence of hepatocellular vacuolization in the surrogate sandbar shiners could lead to underestimation of the risk of the condition in Cape Fear shiners.

In conclusion, our studies have demonstrated the value of small-scale examinations of habitat health risk for endangered species by identifying new potential pathogens not previously reported in the species being studied and uncovering apparently site-specific health differences that warrant more intensive study. The sandbar shiner has been shown to be a potentially valuable surrogate species for the Cape Fear shiner-with some important limitations. Further investigation to evaluate the effects of size or sex distributions on pathologies is necessary to assess the suitability of the sandbar shiner as a valid surrogate. These studies also emphasize the need to develop nonlethal diagnostic techniques for small fishes, to enhance our ability to conduct assessments of habitat health risks on small populations.

\section{Acknowledgments}

This work was supported by USFWS grant 1448-40181-98-G-139 for threatened and endangered species recovery. We thank Tom Augspurger for assistance with study design, permitting, sample collection, funding, and manuscript review; John Alderman and John Fridell for help with permits, species selection, and shiner collection; Judith Johnson for shiner collection; and Monica Mattmüller for histological processing. We also thank Greg Lewbart, Craig Harms, and Felicia
Nutter for use of their field equipment and Edward Noga, Michael Dykstra, Robin Overstreet, Luke Iwanowicz, Andrew Goodwin, Lori Gustafson, and Norman Barlow for lending their specialized expertise to sample interpretation.

\section{References}

Adams, S. M., M. S. Bevelhimer, M. S. Greeley, Jr., D. A. Levine, and S. J. Teh. 1999. Ecological risk assessment in a large river-reservoir: 6. Bioindicators of fish population health. Environmental Toxicology and Chemistry 18:628-640.

Beyers, D. W. 1995. Acute toxicity of Rodeo ${ }^{\circ}$ herbicide to Rio Grande silvery minnow as estimated by surrogate species: plains minnow and fathead minnow. Archives of Environmental Contamination and Toxicology 29:24-26.

Bullock, A. M. 1989. Laboratory methods. Pages 374405 in R. J. Roberts, editor. Fish pathology, 2nd edition. Bailliere Tindall, Philadelphia.

Dubin, S., and S. Zietz. 1991. Sample size for animal health surveillance. Lab Animal 20:29-33.

Elliott, D. G. 1994. General procedures for bacteriology. In J. C. Thoeson, editor. Suggested procedures for the detection and identification of certain finfish and shellfish pathogens, 4th edition. American Fisheries Society, Fish Health Section, Bethesda, Maryland.

Ganzhorn, J., and S. E. LaPatra. 1994. Viral diseases of fish. I. General procedures for virology. In J. C. Thoeson, editor. Suggested procedures for the detection and identification of certain finfish and shellfish pathogens, 4th edition. American Fisheries Society, Fish Health Section, Bethesda, Maryland.

Gardiner, C. H., R. Fayer, and J. P. Dubey. 1988. An atlas of protozoan parasites in animal tissues, 2nd edition. Registry of Veterinary Pathology, Armed Forces Institute of Pathology, American Registry of Pathology, Washington, D.C.

Glantz, S. A. 1997. Primer of biostatistics, 4th edition. McGraw-Hill, New York.

Harrell, R. D., and D. G. Cloutman. 1978. Distribution and life history of the sandbar shiner, Notropis scepticus (Pisces: Cyprinidae). Copeia 1978:443-447.

Hoffman, G. L., and R. Walker. 1978. A new myxosporidian, Dicauda atherinoidi n.g., n. sp., of the minnow, Notropis atherinoides rafinesque. Journal of Fish Diseases 1:343-349.

Hubbs, C. L., and K. F. Lagler. 1958. Fishes of the Great Lakes region. University of Michigan Press, Ann Arbor.

Iwanowicz, L. R., A. E. Goodwin, and N. Heil. 2000. A small RNA virus isolated from apparently healthy wild sandbar shiners, Notropis scepticus (Jordan, and Gilbert). Journal of Fish Diseases 23:349-352.

Jones, S. B., L. B. King, L. C. Sappington, F. J. Dwyer, M. Ellersieck, and D. R. Buckler. 1998. Effects of carbaryl, permethrin, 4-nonylphenol, and copper on muscarinic cholinergic receptors in brain of surrogate and listed fish species. Comparative Biochemistry and Physiology Part C 120:405-414. 
Kime, D. E. 1998. Endocrine disruption in fish. Kluwer Academic Publishers, Boston.

Kimura, D. K., R. R. Mandapat, and S. L. Oxford. 1979. Method, validity and variability in the age determination of yellowtail rockfish (Sebastes flavidus), using otoliths. Journal of the Fisheries Research Board of Canada 36:377-383.

Li, L., and S. S. Desser. 1983. Trichodina algonquinensis, a new species of peritrich ciliate from Ontario freshwater fish, and observations on its transmission. Canadian Journal of Zoology 61:1159-1164.

Maitland, P. S. 1995. The conservation of freshwater fish: past and present experience. Biological Conservation 72:259-270.

McAllister, P. E. 1993a. Freshwater temperate fish viruses. Pages 284-300 in M. K. Stoskopf, editor. Fish medicine. Saunders, Philadelphia.

McAllister, P. E. 1993b. Salmonid fish viruses. Pages 380-408 in M. K. Stoskopf, editor. Fish medicine. Saunders, Philadelphia.

Menhinick, E. F. 1991. The freshwater fishes of North Carolina. North Carolina Wildlife Resources Commission, Raleigh.

Mish, F. C., editor. 1986. Webster's ninth new collegiate dictionary. Merriam-Webster, Springfield, Massachusetts.

Muzzall, P. M., and C. R. Peebles. 1987. Parasites of the emerald shiner, Notropis atherinoides, from two localities in the St. Mary's River, Michigan, with emphasis on larval trematodes. Proceedings of the Helminthological Society of Washington 54:105110.

Myers, M. S., L. L. Johnson, P. Olson, C. M. Stehr, B. H. Horness, T. K. Collier, and B. B. McCain. 1998. Toxicopathic hepatic lesions as biomarkers of chemical contaminant exposure and effects in marine bottomfish species from the Northeast and Pacific coasts, U.S.A. Marine Pollution Bulletin 37:92113.

Noga, E. J. 1996. Fish disease: diagnosis and treatment. Mosby-Year Book, Inc., St. Louis.

Ossiander, F. J., and G. Wedemeyer. 1973. Computer program for sample sizes required to determine disease incidence in fish populations. Journal of Fisheries Research Board of Canada 30:1383-1384.

Pawson, M. G. 1990. Using otolith weight to age fish. Journal of Fish Biology 36:521-531.

Pottern, G. B., and M. T. Huish. 1985. Status survey of the Cape Fear shiner Notropis mekistocholas. U.S. Fish and Wildlife Service, Endangered Species Office, Asheville, North Carolina.

Pottern, G. B., and M. T. Huish. 1986. Supplement to the status survey of the Cape Fear shiner Notropis mekistocholas. U.S. Fish and Wildlife Service, Endangered Species Office, Asheville, North Carolina.
Pottern, G. B., and M. T. Huish. 1987. Second supplement to the status survey of the Cape Fear shiner Notropis mekistocholas. U.S. Fish and Wildlife Service, Endangered Species Office, Asheville, North Carolina.

Purvis, J. R., M. J. Peterson, N. O. Dronen, J. R. Lichtenfels, and N. J. Silvy. 1998. Northern bobwhites as disease indicators for the endangered Attwater's prairie chicken. Journal of Wildlife Diseases 34: 348-354.

Rakes, P. L., J. R. Shute, and P. W. Shute. 1999. Reproductive behavior, captive breeding, and restoration ecology of endangered fishes. Environmental Biology of Fishes 55:31-42.

Roberts, R. J. 1989. The pathophysiology and systematic pathology of teleosts. Pages 94-95 in R. J. Roberts, editor. Fish pathology, 2nd edition. Bailliere Tindall, Philadelphia.

Robinson, A. T., P. P. Hines, J. A. Sorenson, and S. C. Bryan. 1998. Parasites and fish health in a desert stream, and management implications for two endangered fishes. North American Journal of Fisheries Management 18:599-608.

Ruppert, J. B., and R. T. Muth. 1997. Effects of electrofishing fields on captive juveniles of two endangered cyprinids. North American Journal of Fisheries Management 17:314-320.

Snelson, F. F. 1971. Notropis mekistocholas, a new herbivorous cyprinid fish endemic to the Cape Fear River basin, North Carolina. Copeia 1971:449-462.

United States Fish and Wildlife Service. 1988. Cape Fear shiner recovery plan. U.S. Fish and Wildlife Service, Atlanta.

United States Fish and Wildlife Service. 1995. In U.S. Fish and Wildlife Service manual, Fisheries-Fish Health, Release 170, 713 FW. U.S. Fish and Wildlife Service, Washington, D.C.

Warren, M. L., Jr., and B. M. Burr. 1994. Status of freshwater fishes of the United States: overview of an imperiled fauna. Fisheries 19:6-29.

Warren, M. L., Jr., B. M. Burr, S. J. Walsh, H. L. Bart, Jr., R. C. Casher, D. A. Etnier, B. J. Freeman, B. R. Kuhajda, R. L. Mayden, H. W. Robison, S. T. Ross, and W. C. Starnes. 2000. Diversity, distribution, and conservation status of the native freshwater fishes of the southern United States. Fisheries 25: 7-31.

Whittier, T. R., D. B. Halliwell, and S. G. Paulsen. 1997. Cyprinid distributions in Northeast U.S.A. lakes: evidence of regional-scale minnow biodiversity losses. Canadian Journal of Fisheries and Aquatic Sciences 54:1593-1607.

Wootten, R. 1989. The parasitology of teleosts. Pages 242-288 in R. J. Roberts, editor. Fish pathology, 2nd edition. Bailliere Tindall, Philadelphia. 